PROBLEMS

OF MANAGEMENT IN THE $21^{\text {st }}$ CENTURY Vol. 9, No. 2, 2014

124

\title{
INCOME PER BED AS A DETERMINANT OF HOSPITAL'S FINANCIAL LIQUIDITY
}

\author{
Agnieszka Bem \\ Wroclaw University of Economics, Wrocław, Poland \\ E-mail: agnieszka.bem@ue.wroc.pl \\ Paulina Ucieklak-Jeż \\ Jan Dlugosz University in Czestochowa, Czestochowa, Poland \\ E-mail: p.ucieklak-jez@ajd.czest.pl \\ Paweł Prędkiewicz \\ Wroclaw University of Economics, Wrocław, Poland \\ E-mail: pawel.predkiewicz@ue.wroc.pl
}

\begin{abstract}
Hospitals' financial condition is very important, in terms of availability and quality of inpatient health care services. Inpatient's services consume, in Poland, an important part (about 50\%) of National Health Fund resources, but financial situation of hospitals is difficult and many hospitals report problems with liquidity and solvency.

The purpose of this research is to study the relationship between the intensity of care, measured by the annual income per bed, and the static liquidity ratios (current ratio and quick ratio). The research has been conducted on the sample of 138 Polish hospitals, using data covering the period 2009-2011. In order to test research hypotheses, statistical tools have been used (T-Student distribution).

The study has shown, that, during analyzed period, liquidity ratios have lowered and the level of financial liquidity is, in case of Polish hospitals, lower than recommended in the literature. The authors also confirmed the existence of the relationship between annual income per bed and liquidity ratios. However, the most important finding is that the relationship between the hospital's income per bed and financial liquidity ratios is positive only up to a certain level, which has been estimated at about 60,000-70,000 EUR per bed. Above this level further increase in income per bed decreases liquidity ratios. This finding seems to be extremely important for health care managers, which usually strive for the income maximization.

Key words: hospital, financial liquidity, financial management, $C R, Q R$.
\end{abstract}

\section{Introduction}

The hospital is a complex organization, aiming to maximize their statutory goals, by providing a variety of services, while taking into account the internal and external constraints, and demand for inpatient services. Tighter budgets and restructuring processes, taking place in almost every country, have led to higher expectations from patients, the society, health professionals and payers (Minvielle et al, 2008).

Hospitals do not form a homogeneous group. Hence, the financial situation of the individual units can be very diversified, depending strongly on the market processes (Gapenski, Vogel, Langland-Orban, 1993). The factors, that may, potentially, diversify the hospital's activity, and, as a result, financial condition, are as follows:

- form of the ownership - limited liability company or joint-stock company, budgetary unit, independent public health care institution;

- the owner - a public or private body; 
- $\quad$ the aim of activity - non-profit, not-for-profit, for profit;

- $\quad$ the type of hospital - surgical, general, etc.;

and other factors, related to a location (urban-rural areas), degree of specialization, linking medicinal and teaching functions (teaching hospitals).

Regardless of factors, presented above, and adopted objectives (financial and medical), we should accept, that financial balance has a crucial importance for the continuation of a hospital's activity. This balance should be analyzed in longer perspective, providing not only a possibility to cover current costs of the activity, but also investments needed to restore the equipment and fix assets.

The financial situation of the public hospitals in Poland has generally worsened, especially profitability ratios ${ }^{1}$. Profitability cannot be judged as the only criterion for assessing the financial health of the hospital. Literature studies have allowed us to extract, others than profitability, key areas, such as: liquidity, solvency, debt management and assets management, activity (related to the efficiency of the management of enterprises on the market) (McKinney, 2004), (Gunther Lane, Longstreth, Nixon, 2001), (Penner, 2013), (Zeller, Stanko, Cleverey, 1996), (Watkins, 2000), (Cleverley,Harvey, 1992), (Ehreth, 1994).

One of the major concerns is current liabilities' regulation liquidation, which can disrupt the achieving of adopted medical objectives, and even bankruptcy or need for financial support from the owner. A specific consequence of bad financial situation, in case of Polish public hospitals, is forced transformation into the company (private or public), which aims to increase the responsibility for financial management.

This short-term perspective, represented by liquidity ratio is especially important for hospitals, which generally do not operate in their long-run equilibrium and tend to over-invest in capacity and equipment (Smet, 2002).

Literature studies have shown, that the level of liquidity ratio differs significantly between hospitals, and, generally, is lower, than level recommended for enterprises (2.0). Empirical studies have indicated average level of CR equaled to 1.1 (Pink, Daniel, McGillis Hall, Mckillop, 2007), 1.75, while the average CR value for hospitals in the United States was 2.25. At the same time, the level of CR in analyzed groups showed great diversity $(0.4-5.5)$ (Draffin and Tucker LLP, 2011).

The purpose of this research is to study the relationship between the annual income per bed and the static liquidity ratio. Authors have decided to answer the question, whether the income per bed has an impact on the level of financial liquidity, measured using $\mathrm{CR}$ and QR ratio. Two research hypotheses have been formulated:

H1: the income per bed, influences on the level of liquidity ratio;

H2: the correlation between the income per bed is positive up to a certain (not known yet) level. Above this level, the correlation is negative.

H1 hypothesis assumes, that the level of annual income per bed, which shows "intensity of care" influences liquidity ratios. It can be supposed, that hospitals having higher income per bed, should have higher liquidity ratios, what could be associated with the effect of economies of scale, which is related to more efficient use of equipment and human resources.

$\mathrm{H} 2$ hypothesis supposes that the positive relationship is true only up to a certain level, which should be empirically estimated. It can be assumed, that above this level economies of scale are too low to make up for the high level of complexity (and cost), related to the most advanced procedures.

\section{Methodology of Research}

Financial liquidity can be measured using a number of indicators. Selection of indicator is, inter alia, derived from the structure of obtained data. Because of the simplicity of use and 
PROBLEMS

OF MANAGEMENT

IN THE $21^{\text {st }}$ CENTURY Vol. 9, No. 2, 2014

126

the ability to compare the results obtained with those, obtained in other studies, two liquidity ratios have been chosen:

- $\quad$ current ratio $(\mathrm{CR})$, described by formula: current ratio $(\mathrm{CR})=$ (current assets)/ (current liabilities);

- $\quad$ quick liquidity ratio $(\mathrm{QR})$, described by formula: quick ratio $(\mathrm{QR})=$ (current assets - inventories)/ (current liabilities).

Liquidity ratios measure the ability to transform liquid assets into cash, in order to pay off current liabilities. Current ratio is the most commonly used measure of financial liquidity in the health care sector (Pink et.al., 2007), (McLean, 2002), (Briggs, Briggs, 2004, pp. 164-165), (Gunther et al., 2001).Current ratio includes, generally, less liquid assets, such as inventories, in this context, the quick ratio takes into account the assets of large liquidity (cash and equivalents, receivables, short-term investments). In this study, quick ratio has a complementary character.

In this study, the definition of a hospital as an enterprise has been adopted, which has in its organizational structure at least two units: a hospital ward and admission unit, and has a code 1 , according to the classification of medical enterprises. To this research, hospitals, owned by local public bodies, have been qualified, irrespective legal form of activity (independent public health care institution - SPZOZ, limited liability company or joint-stock company), on condition that the most of the stock/share is held by units of local government (hospitals controlled by local government bodies). Psychiatric hospitals have been excluded from the study, due to the nature of their activity and financing.

In Poland (2013) operate 440 hospitals, which are under the control of the local government units (compared to all hospitals in Poland - 878) (Centrum Systemów Informacyjnych Ochrony Zdrowia, 2012).

In order to create the research sample, a stratified sampling has been applied. The sampling has been carried out independently in each layer. The number of layers has been set taking into account the diversity, while maintaining proportionality, using the optimal Neyman's scheme:

$n_{h}=n \times \frac{N_{h} S_{h}}{\sum N_{h} S_{h}}=n \times \frac{W_{h} S_{h}}{\sum_{h=1}^{l} W_{h} S_{h}}$

(1)

where:

$\mathrm{n}$ - total strength of the sample,

$N_{h}$ - strength of the h-layer in population,

$W_{h}=\frac{N_{h}}{N}$

$\mathrm{N}$-total strenght of the population,

$S_{h}$ - standard deviation in h-layer.

Assuming, that 440 hospitals constitute the whole analyzed population, the number of observations has been specified, so that it has been possible to draw conclusions about the population, characterized by a certain degree of certainty and precision.

The number of the sample has been determined, according to the formula $(\mathrm{Xu}, 1999)$ : $n=\frac{Z(p(1-p)}{d^{2}}$

where:

$\mathrm{n}$ - strength of the sample;

Z -Z-Statistic for desired confidence level;

$p-$ the estimate of the expected proportion of the variable in the population;

d- $1 / 2$ of desired confidence level. 
For the confidence level of $95 \%$, Z-Statistic equal 1.96 and for confidence level of $99 \%$ 2.58. Adopting $\mathrm{p}=0.10$ and $\mathrm{d}=0.05$, the strength of the sample has been estimated as follows (Rószkiewicz, 2002):

$$
\mathrm{n}=\frac{1.96^{2}(0.1(1-0.1)}{0.05}=138.3
$$

According to that, finally, 138 hospitals have been selected.

The study has required creating the database. We have analyzed financial data coming from 138 public hospitals in Poland. Financial data on revenues, assets and liabilities, coming from Amadeus Database, have been supplemented by organizational information, concerning, for example, the number and structure of beds, which has been obtained from the Registry of Medical Entities (http://rpwdl.csioz.gov.pl/). Analysis has covered data from the years 20092011.

Hypotheses, formulated during initial stages of research, have required the appraisal of the relationship between annual income per one bed and the level of current liquidity (CR) and quick liquidity $(\mathrm{QR})$ ratios. The strength and the direction of the relationship have been measured using the Pearson correlation coefficient, using the formula:

$$
r_{y}=\frac{\frac{1}{n} \cdot \sum_{i=1}^{n}\left(x_{i}-\bar{x}\right) \cdot\left(y_{i}-\bar{y}\right)}{s_{x} \cdot s_{y}}
$$

Then, the statistical significance of obtained correlation coefficients has been tested, assuming the following construction of research hypothesis:

$\mathrm{HO}$ : the correlation coefficient is insignificant statistically (null hypothesis);

$\mathrm{H} 1$ : the correlation coefficient is statistically significant;

For which the test is statistic:

$$
t_{e}=\frac{r}{\sqrt{1-r^{2}}} \sqrt{n-2}
$$

that, assuming the validity of H0 hypothesis has the T-Student distribution with $\mathrm{n}-2$ degrees of freedom.

\section{Results of Research}

In order to estimate the extent of the problem, descriptive statistic for the whole sample has been calculated (Table 1). The average value of CR has lowered relevantly during analyzed period and in 2011 reached the level equaled 0.890. During the overall period QR ratio has received lower values than the CR and also has lowered during 2009-2011 years.

Table 1. Descriptive statistic for current ratio, whole sample, years 2009-2011.

\begin{tabular}{lllllllll}
\hline \multicolumn{3}{c}{ CR } & \multicolumn{7}{c}{ QR } \\
\hline & Mean & Min. & Max. & Standard deviation & Mean & Min. & Max. & Standard deviation \\
\hline $\mathbf{2 0 0 9}$ & 1.327 & 0.240 & 4.816 & 0.731 & 1.220 & 0.224 & 4.631 & 0.850 \\
\hline $\mathbf{2 0 1 0}$ & 1.186 & 0.177 & 4.793 & 0.854 & 1.083 & 0.161 & 4.618 & 0.805 \\
\hline $\mathbf{2 0 1 1}$ & 0.890 & 0.165 & 5.537 & 0.897 & 0.795 & 0.138 & 5.316 & 0.668 \\
\hline \multicolumn{3}{l}{ Source: own study } & & & & &
\end{tabular}


PROBLEMS

OF MANAGEMENT

IN THE $21^{\text {st }}$ CENTURY Vol. 9, No. 2, 2014

Analysis of the relationship between indicators of liquidity (both CR and QR) and annual income on the bed has indicated, that there is a positive correlation between these variables. The correlation is of average strength, but highly statistically significant (Table 2). On the significance level $\alpha<0.01$ the H1 hypothesis can be accepted, provided that this relationship hasn't occurred in 2009, what shows the need for further research.

Table 2. Correlation between financial liquidity ratios and annual income per bed.

\begin{tabular}{|c|c|c|c|c|}
\hline \multirow{2}{*}{ Year } & \multicolumn{2}{|l|}{ CR } & \multicolumn{2}{|l|}{$Q R$} \\
\hline & $\mathbf{R}_{\mathrm{xy}}$ & $p$ & $\mathbf{R}_{\mathrm{xy}}$ & $p$ \\
\hline 2009 & 0.0605 & 0.2540 & 0.0519 & 0.2851 \\
\hline 2010 & 0.3243 & $0.0001^{* * *}$ & 0.3132 & $0.0002^{\star * \star}$ \\
\hline 2011 & 0.4445 & $0.0000^{* * *}$ & 0.4783 & $0.0000^{* * *}$ \\
\hline
\end{tabular}

In order to prove the $\mathrm{H} 2$ hypothesis, hospitals have been split into 3 groups, according to the level of annual income per 1 bed. There can be observed the positive relationship between liquidity ratio (both $\mathrm{CR}$ and QR) and income per bed in hospitals with small and average income per bed and negative relationship for hospitals with highest intensity of care (Table 3). That allows to accept, on the significance level $\alpha<0.05$, the H2 hypothesis.

Table 3. Correlation between financial liquidity ratios and annual income per bed, hospital split into groups.

\begin{tabular}{|c|c|c|c|c|c|}
\hline \multirow{2}{*}{ Year } & \multirow{2}{*}{$\begin{array}{l}\text { Annual income per bed (thousands } \\
\text { of PLN) }\end{array}$} & \multicolumn{2}{|l|}{ CR } & \multicolumn{2}{|l|}{ QR } \\
\hline & & $\mathbf{R}_{\mathrm{xy}}$ & $p$ & $\mathbf{R}_{\mathrm{xy}}$ & $\mathbf{p}$ \\
\hline \multirow{3}{*}{2009} & up to129 & 0.2538 & $0.0771^{*}$ & 0.2571 & $0.0743^{*}$ \\
\hline & $129-258$ & 0.1937 & $0.0480^{* *}$ & 0.1771 & $0.0642^{*}$ \\
\hline & higher than 258 & -0.5732 & $0.0326^{* *}$ & -0.6486 & $0.0154^{* *}$ \\
\hline \multirow{3}{*}{2010} & up to 127.42 & 0.3271 & $0.0388^{\star *}$ & 0.3279 & $0.0384^{* *}$ \\
\hline & $127.42-208$ & 0.2306 & $0.0334^{* *}$ & 0.2419 & $0.0271^{* *}$ \\
\hline & higher than 208 & -0.5956 & $0.0346^{* *}$ & -0.5481 & $0.0505^{\star}$ \\
\hline \multirow{3}{*}{2011} & up to 133 & 0.3358 & $0.0434^{* *}$ & 0.2909 & $0.0705^{*}$ \\
\hline & $133-316$ & 0.1994 & $0.0362^{* *}$ & 0.2016 & $0.0346^{* *}$ \\
\hline & higher than 316 & -0.6650 & $0.0360^{* *}$ & -0.6793 & $0.0320^{* *}$ \\
\hline
\end{tabular}

* significance level $\alpha=0.1$, ** significance level $\alpha=0.05^{* * *}$ significance level $\alpha=0.01$

Source: own study 
The literature review suggests, that the recommended level of current liquidity ratio for hospitals, should be about 2.0. This means, that it does not diverge from the level of liquidity recommended for commercial companies. This observation coincidence with results of research, carried out in American hospitals, for which the average level of the CR index equaled to 2.25 .

The analysis has shown that Polish hospitals are characterized by generally lower (according to other studies) level of liquidity. What is important, liquidity ratios, during analyzed period, has lowered, both in case of CR and QR ratio. The average level of the CR in 2009 was 1.327 , while in $2011-0.890$. In the case of QR it was 0.795 and 1.220 , respectively. Liquidity is not only low but also decreased in the subsequent years tested $(49 \%$ for CR and $53 \%$ for QR). It should be pointed out, that there is relatively little difference between the value of the $\mathrm{CR}$ and the QR ratio. That suggests, that stocks (inventories) do not play a significant role as a component of the hospital's current asset - inventories relate primarily to drugs and disposable materials, and they are subject to considerable rotation.

The study has proved the statistically significant relationship between the annual revenue per one bed and the level of liquidity (measured both by CR and QR). This means, that the increase in "the intensity of care" influences positively on the level of financial liquidity. The strength of this relationship increases in subsequent years, together with a decrease in the average level of liquidity.

This observed relationship is generally true for hospitals of small and medium intensity care, with annual income per one bed lower than the 60,000 - 70,000 EUR. In the case of hospitals with the lowest income per 1 bed (less than 30,000 EUR) the strength of this positive relationship is higher than in the case of hospitals with an average income per bed (30,000-60,000 EUR). So, for hospitals characterized by small and medium income per bed, increasing revenue improves liquidity indicators.

There has also been observed, that with the increase in the average liquidity, the strength of the relationship grows (increasing correlation coefficients).In the case of hospital, characterized by high income per one bed (higher than 60,000-70,000 EUR), further increase in income decreases, both $\mathrm{CR}$ and $\mathrm{QR}$, ratios.

The interpretation's limitation, in this case, is related to the fact, that this relationship hasn't been observed in 2009, and obtained correlation coefficients are of moderate strength, despite of the very high statistical significance. A limitation of the analysis is related to the different income ranges in every analyzed year. For this reason, the study should be carried out again using a larger sample.

Results presented above are difficult to compare to other studies, because literature review doesn't provide a clear evidence in this area. Previous studies, conducted primarily in the United States, focused on the analysis of profitability or the hospital's optimum size, from the point of view of profitability. This indicates the need for broader comparative research, because liquidity may affect hospital's performance even more than profitability, which, on the other hand, can always be seen as the primary aim of activity.

\section{Conclusions}

The intensity of care, which can be expressed as the volume of the annual revenue generated by one bed, is a very important indicator in the assessment of the hospital's activity. Usually, it is assumed, that the higher the income per one bed is, the better is the financial condition of the hospital. It is also believed, that this is due to the better exploitation of beds (for example shorter average length of stay) or providing more advanced procedures. That's why, the primary aim of each health care manager is, to increase the revenues generated by one hospital bed. This research supports, to some extent, this assertion, because it seems, that increase in revenue per bed improves liquidity. 
Agnieszka BEM, Paulina UCIEKLAK-JEŻ, Paweł PRĘDKIEWICZ. Income Per Bed as a Determinant of Hospital's Financial Liquidity

PROBLEMS

OF MANAGEMENT

IN THE $21^{\text {st }}$ CENTURY Vol. 9, No. 2, 2014

However, the most important conclusion of the study is, that above a certain level, increase in revenue is negatively correlated with financial liquidity. This finding is of particular importance for hospitals that provide highly specialized procedures. Due to some limitation, mentioned above, conclusions should be considered preliminary, and certainly they require retesting, conducted on a larger sample.

\section{References}

Centrum Systemów Informacyjnych Ochrony Zdrowia. (2012). Biuletyn Statystyczny Ministerstwa Zdrowia za 2011 rok. Warszawa.

Cleverley, W. Harvey, R. (1992). Does hospital financial performance measure up? Healthcare Financial Management, 46 (5), 20-25.

Draffin and Tucker LLP. (2011). Executive Summary. Critical Access Hospital Financial Analyses. Retrieved from https:/dch.georgia.gov/sites/dch.georgia.gov/files/imported/vgn/images/ portal/cit_1210/45/59/181525469Executive_Summary_Critical_Access_Hospital_Financial_ Analyses_2012.pdf, 63-80.

Ehreth, J. L. (1994). The development and evaluation of hospital performance measures for policy analysis. Medical Care, 6, 568-587.

Gapenski, L., Vogel, W., Langland-Orban, B. (1993). The determinants of hospital profitability. Hospital and Health Services Administration, 1, 63-80.

Gunther Lane, S., Longstreth, E., Nixon, V. (2001). A community leader's guide to hospital finance. Evaluating how a hospital gets and spends its money. Boston: Harvard School of Public Health.

McKinney, J. B. (2004). Effective financial management in public and nonprofit agencies. Greenwood Publishing Group.

Minvielle, E., Sicotte, C., Champagne, F., Contandriopoulos, A., Jeantet, M., Preaubert, N. (2008). Hospital performance: Competing or shared values? Health Policy, 87, 8-19.

Penner, S. J. (2013). Economics and financial management for nurses and nurse leaders: Second Edition. New York: Springer Publishing Company.

Pink, G. H., Daniel, I., McGillis Hall, L., Mckillop, I. (2007). Selection of key financial indicators: A literature, panel and survey approach. Healthcare Quarterly, 1, 87-96.

Rószkiewicz, M. (2002). Metody ilościowe wbadaniach marketingowych. Wydawnictwo Naukowe PWN. Warszawa.

Smet, M. (2002). Cost characteristics of hospitals. Social Science \& Medicine, 6, 895-906.

Watkins, A. L. (2000). Hospital financial ratio classification patterns revisited: Upon considering nonfinancial information. Policy, Journal of Accounting and Public, 1, 73-95.

Xu, G. (1999). Estimating sample size for a descriptive study in quantitative research. Quirk's Marketing Research Review, 1, 13-`17.

Zeller, T. L., Stanko, B. B., Cleverey, W. O. (1996). A revised classification pattern of hospital financial ratios. Journal of Accounting and Public Policy, 2, 161-181.

Advised by Judita Stankutè, SMC “Scientia Educologica”, Lithuania

Received: May 09, 2014

Accepted: July 08, 2014 
Agnieszka BEM, Paulina UCIEKLAK-JEŻ, Paweł PRĘDKIEWICZ. Income Per Bed as a Determinant of Hospital's Financial Liquidity

PROBLEMS

OF MANAGEMENT

IN THE $21^{\text {st }}$ CENTURY

Vol. 9, No. 2, 2014

131

\begin{tabular}{|ll|} 
Agnieszka Bem & $\begin{array}{l}\text { Ph.D., Assistant Professor, Wroclaw University of Economics, International } \\
\text { and Public Finance Department, Komandorska 118/120, 53-345 Wroctaw, } \\
\text { Poland. } \\
\text { E-mail: agnieszka.bem@ue.wroc.pl }\end{array}$ \\
\hline Paulina Ucieklak-Jeż & $\begin{array}{l}\text { Ph.D., Assistant Professor, Jan Dlugosz University in Czestochowa, Faculty } \\
\text { of Social Science, Waszyngtona 4/8, 42-200 Częstochowa, Poland. } \\
\text { E-mail: p.ucieklak-jez@ajd.czest.pl }\end{array}$ \\
\hline Paweł Prędkiewicz & $\begin{array}{l}\text { Ph.D., Assistant Professor, Wroclaw University of Economics, Department } \\
\text { of Finance, Komandorska 118/120, 53-345 Wrockaw, Poland. } \\
\text { E-mail: pawel.predkiewicz@ue.wroc.pl }\end{array}$
\end{tabular}

